\title{
Inventory of the potato diseases and impact on growth and yield traits in far North Cameroon
}

\author{
Jules Patrice NGOH DOOH ${ }^{1 *}$, Frederic Ulrich BOYDOUL ${ }^{1,2}$, \\ Abdoul MADJEREMBE ${ }^{1,3}$, Dany Brice TCHOUPOU TSOUALA ${ }^{1,4}$, \\ Djile Bouba HAWAOU ADAGORO ${ }^{2}$, Philippe KOSMA ${ }^{3}$ and Zachée AMBANG ${ }^{4}$ \\ ${ }^{I}$ Department of Biological Sciences, Faculty of Science, University of Maroua, PO Box 814 Maroua, \\ Cameroon. \\ ${ }^{2}$ Institute of Agricultural Research for Development of Maroua (IRAD), PO Box 33, Cameroon. \\ ${ }^{3}$ Higher National Polytechnic School of Maroua, University of Maroua, PO Box 1450 Maroua, Cameroon. \\ ${ }^{4}$ Laboratory of Biotechnologies, Phytopathology and Microbiology Unit, University of Yaounde I, \\ PO Box, 812, Cameroon. \\ *Corresponding author; E-mail: ndjuliopat@yahoo.fr; Tel.: (+237) 699219391
}

\begin{abstract}
Potato (Solanum tuberosum L) production in the Far North Region of Cameroon is faced with scarcity or inequality of rains and with diseases that affect yields. To improve the production a study was conducted in the production area of Mogode subdivision with the objective of identifying potato diseases and pathogens agents. The experimental design was in complete randomized blocks. The plant material used was a local variety of potato (Dosa). Diseases and pathogens have been identified on a base of symptoms and morphological characteristics. The incidence, severity and rainfall were assessed. Yield, number of stems and diameter of the tubers were evaluated. The diseases identified are fungal (late blight, Alternaria or early blight and Fusarium wilt), viral (Virosis M, Rust stain and Potato leaf roll (PLR) and bacterial (Bacterial wilt and Common scab). Conidia of Phytophthora infestans, and Alternaria spp. were found. Whatever the site and disease, the incidence has remained below $25 \%$. Late blight was more present in the Gouria site, Alternaria and virosis M more present in the Mouvou site. The yield was roughly the same at the two sites, around $3 \mathrm{t} / \mathrm{ha}$. The highest number of stems was obtained at Gouria, $18 \pm 0.75$. The potato is attacked by several diseases. The results of this study represent an important baseline data for the implementation of integrated disease management in Cameroon.
\end{abstract}

(C) 2020 International Formulae Group. All rights reserved.

Keywords: Solanum tuberosum, diseases, pathogens, incidence, severity, yield.

\section{INTRODUCTION}

The potato (Solanum tuberosum L.) occupies a preponderant place in the food of many countries by the surfaces which it occupies, the jobs which it provides and the volumes of production which it generates. World production was estimated at more than
368 million tonnes on 19.4 million hectares in 2013 (Issa et al., 2017). The potato occupies the fourth place after the wheat, rice and corn crops. It is therefore the main non-cereal foodstuff in the world (FAO, 2009).

In Cameroon, potato is cultivated in areas of high altitudes, especially by small 
farmers (IRAD, 2012). Six of the ten regions are concerned, the North-West, the SouthWest, the West, Adamawa, the Littoral and the Far -North (Fontem et al., 2005). It constitutes a basic food for the populations of these regions (annual consumption of 4 to $10 \mathrm{~kg}$ per inhabitant/year), an important source of income, because part of production is either sold in the local market, or exported to the neighboring countries. National production was estimated at 229000 tonnes over 23500 hectares in 2009 (IRAD, 2012). Thus, despite the importance of the potato in the national economy, total production remains below real potential, yields are generally low (Njualem et al., 2001; Diop et al., 2019) and are between 3 and 11tonnes per hectare, while those of european countries are on average 25 tonnes per hectare ha and reach 60 tonnes per hectare. In the Far North Cameroon Region, particularly in the Mogodé subdivision (MayoTsanaga), the only and main production area, the low yields observed are associated with poor peasant farming practices (Ngoyi et al., 2020), the scarcity or inequality of the rains and especially to diseases and pests. Many diseases have been reported on potatoes in several countries (Masum et al., 2011; Habtamu et al., 2012; Alkher et al., 2015; Son et al., 2018) and in Cameroon (Fontem et al., 2003; Fontem et al., 2005; Lontsi et al., 2019). Late blight (Phytophthora infestans) and Alternaria or early blight (Alternaria spp) appear to be the major fungi diseases threatening production of potato in the world with more $80 \%$ of losses (Abuley and Nielsen 2017; Ah-Fong et al., 2017). Potato crop losses due to bacterial diseases could be direct or indirect. Brown rot and Bacterial wilt (Ralstonia solanacearum) of potato are the major bacterial diseases in potato production area (Kong et al. 2016; Prior et al. 2016; Charkowski, 2020). Whereas more than 50 different viruses and one viroid have been reported infecting potatoes worldwide only a handful of them cause major losses globally (Chiunga and Valkonen, 2013). PVY and PLRV (potoato leafroll virus) are now the most damaging viruses of potato world-wide, with PVY having overtaken PLRV as the most important. Tuber yield losses are caused by either of them in single infections and can reach more than $80 \%$ in combination with other viruses. PVX occurs commonly worldwide and causes losses of $10-40 \%$ in single infections and is particularly damaging in combination with PVY or PVA (Baldo et al., 2010).

However, no study has been conducted to assess the nature and impact of potato diseases in the locality of Mogodé, Cameroon. The objective of this work was to inventory potato diseases in the district of Mogodé (Mayo-Tsanaga) in the far north, Cameroon. This work will give a better understanding of pathogen organisms involved in the diseases expression and serves as towards diseases management.

\section{MATERIALS AND METHODS Area of study}

Study was conducted in two sites. Mouvou (10 $0^{\circ} 53^{\prime} 867^{\prime}, \mathrm{N}-13^{\circ} 61$ ' 387' 'E) and Gouria (10 $\left.56^{\prime} 665^{\prime}, \mathrm{N}-13^{\circ} 58^{\prime} 771^{\prime} \mathrm{E}\right)$. The two sites are $10 \mathrm{~km}$ apart.

\section{Experimental design}

The experimental design was in complete blocks (03) with 60 plants of local variety (Dosa) per block., i.e. 180 plants per site. In total, almost 360 seed of potatoes were monitored for the trial at the two sites. Each site had an area of $52.5 \mathrm{~m}^{2}$.

The sowing was direct according to the spacings of $80 \mathrm{~cm}$ between the rows and $25 \mathrm{~cm}$ between the pockets. Each pocket, contains 1 pre-closed tuber. The sowing depth was approximately $5 \mathrm{~cm}$. Each bag received approximately $20 \mathrm{~g}$ of fertilizer NPK.

\section{Identification of diseases and pathogen agents}

The diseases were identified using several identification keys (Kamaluddin, 1970; Radtke and Rieckmann, 1991; Delleman et al., 2005). For viral diseases, the observation of typical symptoms was enough in the field since viruses cause some symptoms of their own such as mosaics (Lepoivre, 2003). For fungal diseases, in addition to the symptoms observed in the fields, fungi spores were observed using an optical microscope (Omax) in the 
laboratory. Conidia were identified using identification keys. Two (2) methods were used, culture in a humid chamber and culture in a culture medium. Potato Dextrose Agar (PDA) and Water Agar (WA) were used.

The samples were collected in the morning and taken to the laboratory. Once in the laboratory, the part of the organs showing symptoms was circumscribed and cut using a sterilized blade (with the Bunsen burner) in the laminar flow hood. The leaves were cleaned first with tap water and then in $70{ }^{\circ} \mathrm{C}$ alcohol and $2 \%$ bleach for 3 minutes (Uaciquete, 2013). Then they were put in the culture media (WA, PDA) previously prepared. For humid room, the filter paper was cut and placed at the bottom of the sterile Petri dishes. A few drops of sterile distilled water were added to maintain humidity, and then the diseased organs were introduced into it. Preparations were incubated on photoperiod 12/12h. After four (4) to seven (7) days, the boxes were taken out for the observation of spores. Direct observations were done for the samples with the mycelium in the field.

\section{Assessment of disease development in treatments}

The incidence and severity of the diseases were assessed in the field 15, 30 and 45 days after sowing (DAS). The infected leaves were remove after to avoid twice counts. Rainfall was assessed during the two planting seasons using a rain gauge.

\section{Assessment of the incidence of the diseases observed}

Incidence of diseases were evaluated using the following formula: $I(\%)=\frac{n p}{N} \times$ 100 .With I: incidence; n: number of plants showing symptoms per plot; and $\mathrm{N}$ total number of planting plot.

\section{Assessment of the severity of the diseases observed}

The severity of the disease was assessed by estimating the leaf area occupied by thesymptoms of the disease using the formula: $=\frac{\sum \mathrm{nXI}}{\mathbf{N}} \times 100$. With $\Sigma$ : the sum of the products between the number of diseased plants (a) and the number of plants with the index given in\% (b); $\mathrm{N}$ : the total number of plants in the plot. The severity index used is as follows: $0=$ no symptoms; $1=25 \%$ of diseased leaves; $2=50 \%$ of diseased leaves; $3=75 \%$ of diseased leaves; $4=100 \%$ diseased leaves. The number of diseased leaves per plant was associated with this index.

\section{Evaluation of growth and agronomic parameters}

The growth parameters such as the number of stems and the diameter of the tubers (using a caliper) were carried out on 25 plants of each plot unit.

The harvest was carried out 90 DAS when the leaves turned yellow and curved at the level of the collar. The mass $(\mathrm{kg})$ of the tubers was determined using a balance (SANTOPLUS brand) It consisted of weighing the tubers of 25 plant samples per plot unit (Block). Then, the weight per plot unit was added to obtain the mass of tubers on the site. By extrapolation, the yield per hectare was estimated for each treatment from the area of each plot unit and the weight of the tubers by treatment using the following formula:

Yield $(\mathrm{t} / \mathrm{ha})=($ Yield of the PU x 10000 $\left.\mathrm{m}^{2}\right) /(\mathrm{S}) \times 100$ (Issa et al., 2017).

With S: area of the plot unit (block) and $10000 \mathrm{~m}^{2}$ the area of one hectare and PU the weight of the tubers harvested per plot unit

\section{Measure of Rainfull}

The data were collected using two rain gauges installed in the middle of the fields at Mouvou and Gouria. Each graduated rain gauge consisted of a conical tube, hung on a wooden support. The rainfall was recorded after each rain by measuring the height of the water in the gauge.

\section{Data analysis}

Data collected were subjected to analysis of variance (ANOVA) and means were separated using the Duncan's multiple range test (5\%). SPSS 16.0 software was used. 


\section{RESULTS}

\section{Diseases and pathogens agents identified}

Nine diseases have been identified. Late blight, Alternaria (early blight), Fusarium wilt, Virosis M, Rust stain, PLR, Bacterial wilt and Common scab.

Potato late blight has affected all plant organs (leaves, stems and tubers). The characteristic symptoms are: rounded brown spots, with a yellow halo visible on the upper surface of the leaves which eventually dry out (Figure 1A). A cut of the affected tubers showed marbled areas of brown color on the surface which may extend towards the center of the tuber (Figure 1B). Microscopic observation of the cultures revealed the presence of numerous ovoid to ellipticalshaped tapering sporangia at the base (Figure 1J). These sporangia belong to the fungus Phytophthora infestans.

The first symptoms of alternaria appear on older leaves before spreading to the rest of the foliage. These are small, more or less circular brown spots scattered on the upper surface of the leaves (Figure 1C). Microscopic observation of the cultures revealed two types of spores with variable shapes depending on the species. These are Alternaria solani and Alternaria alternata. They all have septate conidia with dark brown colors. However, Alternaria solani is elongated (Figure $1 \mathrm{~K}$ ) unlike A. alternata which is ovoid (Figure 1L).

Virosis $M$ is characterized by a soft rolling of the summit leaves as well as mosaics on the leaf blade (Figure 1D). The agent responsible for potato $\mathrm{M}$ disease (Virosis $\mathrm{M}$ ) is PVM (Potato virus M), a phytovirus from the Betaflexiviridae family. The characteristic symptoms of the rust stain are red-brown spots scattered on the upper and lower sides of the leaves (Figure 1E). The disease is caused by a virus.The symptoms of PLR are: a rolling of the young leaves which lose flexibility, then become hard and crunchy.The leaves become discolored and turn pale green then yellow at the tips (Figure 1F). The potato leaf curl virus is PLRV (potato leaf roll virus), a virus of the Luteoviridae family.

Bacterial wilt is a disease caused by a bacteria called Pseudomonas solanacearum.
Symptoms are drying of the whole plant (Figure 1G). Fusarium rot is observed on tubers from harvest. The affected tubers show browning, rotting at the end of the tuber, which eventually bursts on mechanical contact (Figure 1H). The agent responsible for the disease is a fungus of the genus Fusarium.

Common scab symptoms on the tubers are surface patches, dark brown to black, and more or less deep perforations or lesions that sink into the inside of the tubers (Figure 1I). They are caused by bacteria belonging to the genera Streptomyces.

\section{Appearance of diseases according to the phenological stages of potato}

The appearance of diseases occurred at both sites depending on the stages of development of the plant. PLRV occurred only on gemination stage in Gouria site. However, virose $M$, alternaria and rust stain occurred during the growth. Alternaria, virosis $\mathrm{M}$ and rust stain all appeared in the vegetative growth phase and progressed to flowering at both sites. Although late blight appeared at both sites during the vegetative growth phase, it evolved until the tubers were harvested. Bacterial wilt has been observed during the flowering phase in Gouria. Tuber diseases such as Fusarium wilt and common scab appeared at harvest (Figure 2).

\section{Diseases incidence}

Analysis of the incidence of diseases showed a highly significant difference $(\mathrm{P}=$ 0.009). Late blight had the highest incidence $19.75 \%$ in Gouria, while rust stain, virus $M$ and alternaria had low incidences, 6.1, 6.2 and $7.1 \%$ respectively. The incidences of these last three diseases were higher in Mouvou compared to Late blight. Bacterial wilt and potato leaf roll were only present in Gouria with very low incidences of around $2 \%$. Whatever the site and the disease, the incidence remained below 25\% (Figure 3).

\section{Diseases Severity}

Virosis $\mathrm{M}$ was more severe in Gouria $(28.27 \pm 5.1 \%)$ while in Mouvou it was late 
blight $(22.49 \pm 6.5 \%)$ and alternaria $(22.16 \pm$ $4.0 \%$ ) who were more severe.

On average, alternaria and late blight were the most severe diseases, however this severity remained low, less than $30 \%$ (Table 1).

\section{Rainfall in the two sites}

Rainfall varied from $0 \mathrm{~mm}$ (week 1 of June) to $1620 \mathrm{~mm}$ (week 2 of September) at the Mouvou site. the rainiest month was september. The peaks were obtained in the $2^{\text {nd }}$ week of September in Mouvou (1620 mm) and Gouria $(1800 \mathrm{~mm})$. The rainfall was higher in the Gouria site (716.5 $\mathrm{mm}$ of water) unlike the
Mouvou site which received $679 \mathrm{~mm}$ of water (Figure 4).

\section{Diameter, number of stems and yield (t/ha)}

No significant difference was obtained between the average tuber diameters at the two sites $(\mathrm{P}>0.05)$. The tubers had substantially equal diameters, $3.24 \pm 0.61$ and $3.34 \pm 0.75$ $\mathrm{cm}$ respectively in Mouvou and Gouria. The yield was almost identical at the two sites (3.80 $\mathrm{t} / \mathrm{ha})$ at Gouria and (3.52 t/ha). The number of stems $(\mathrm{P}=0.001)$ varied from $2 \pm 1.38$ (Mouvou) to18 \pm 0.75 (Gouria) (Table 2).
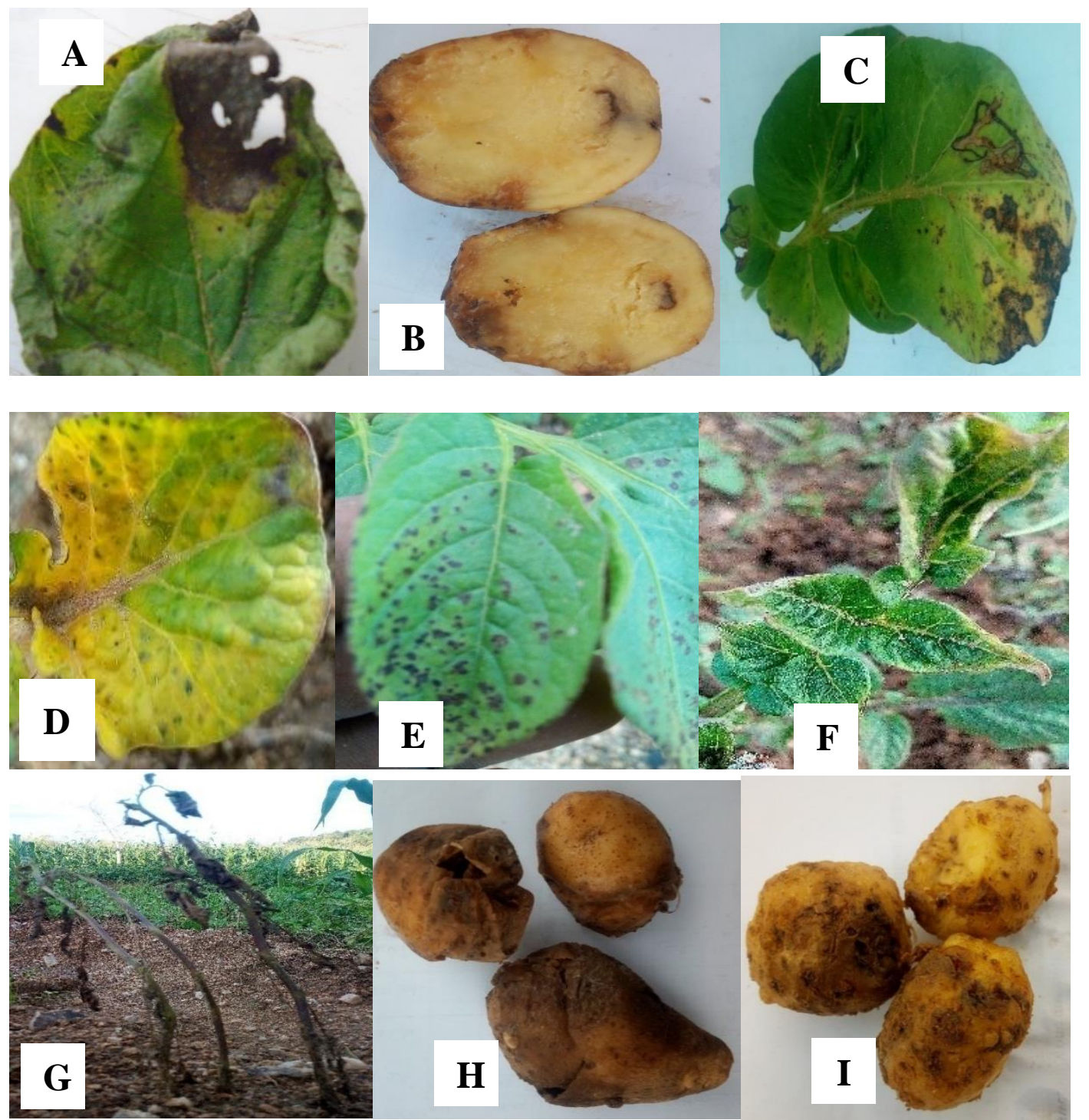

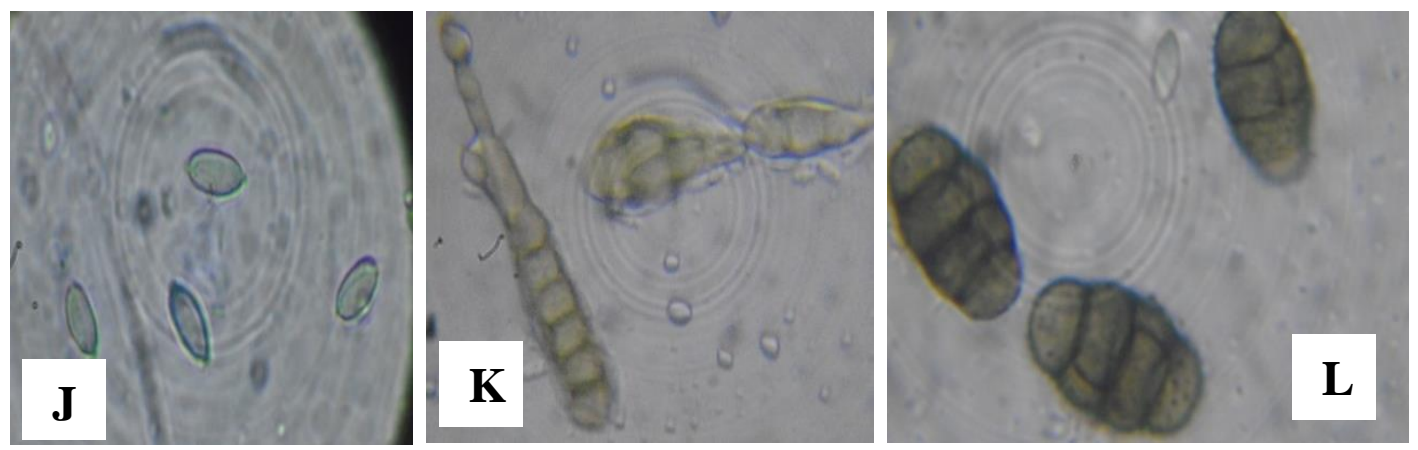

Figure 1: Symptoms and conidia of potato diseases observed. Late blight (A et B): Alternaria (C); Virosis M (D); rust stain (E); PLR (F); Bacterial wilt (G); Fusarium rot (H); Common scab (I); Sporangia of Phytophthora infestans (J); Conidia of Alternaria solani (K) and A. alternata (L).

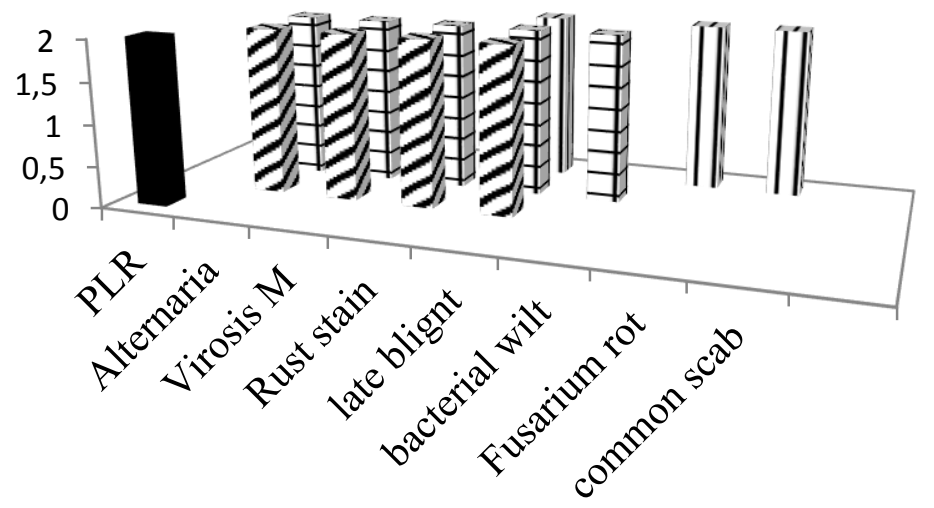

-Germination $\quad$ Growth $\quad$ Flowering ॥ harvest

Figure 2: Appearance of diseases according to the phenological stage.

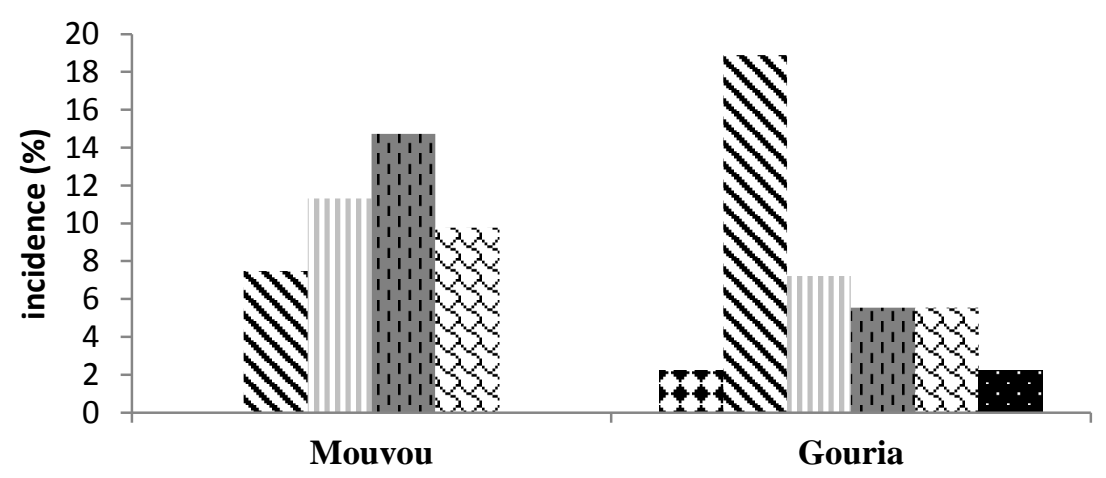

I PLR vlate blight || Alternaria Girosis M

Figure 3: Average diseases incidence in the two sites. 
Table 1: Severity of diseases in the two sites.

\begin{tabular}{cccc}
\hline Sites & Diseases & Average severity (\%) & Probability \\
\hline \multirow{3}{*}{ Mouvou } & Late blight & $14.89 \pm 2.0^{\mathrm{b}}$ & \\
& Alternaria & $10.82 \pm 1.6^{\mathrm{a}}$ & \\
& Virosis M & $28.27 \pm 5.1^{\mathrm{c}}$ & $\mathrm{P}=0.030$ \\
& Rust stain & $9.83 \pm 0.7^{\mathrm{a}}$ & \\
Gouria & Late blight & $22.49 \pm 6.5^{\mathrm{b}}$ & \\
& Alternaria & $22.16 \pm 4.0^{\mathrm{b}}$ & \\
& Virosis M & $8.33 \pm 1.1^{\mathrm{a}}$ & $\mathrm{P}=0.023$ \\
& Rust stain & $21.11 \pm 3.5^{\mathrm{b}}$ & \\
& PLR & $8 \pm 1.0^{\mathrm{a}}$ & \\
\hline
\end{tabular}

The values followed by the same letter in the same site are not significantly different at the 5\% threshold according to Duncan's test.

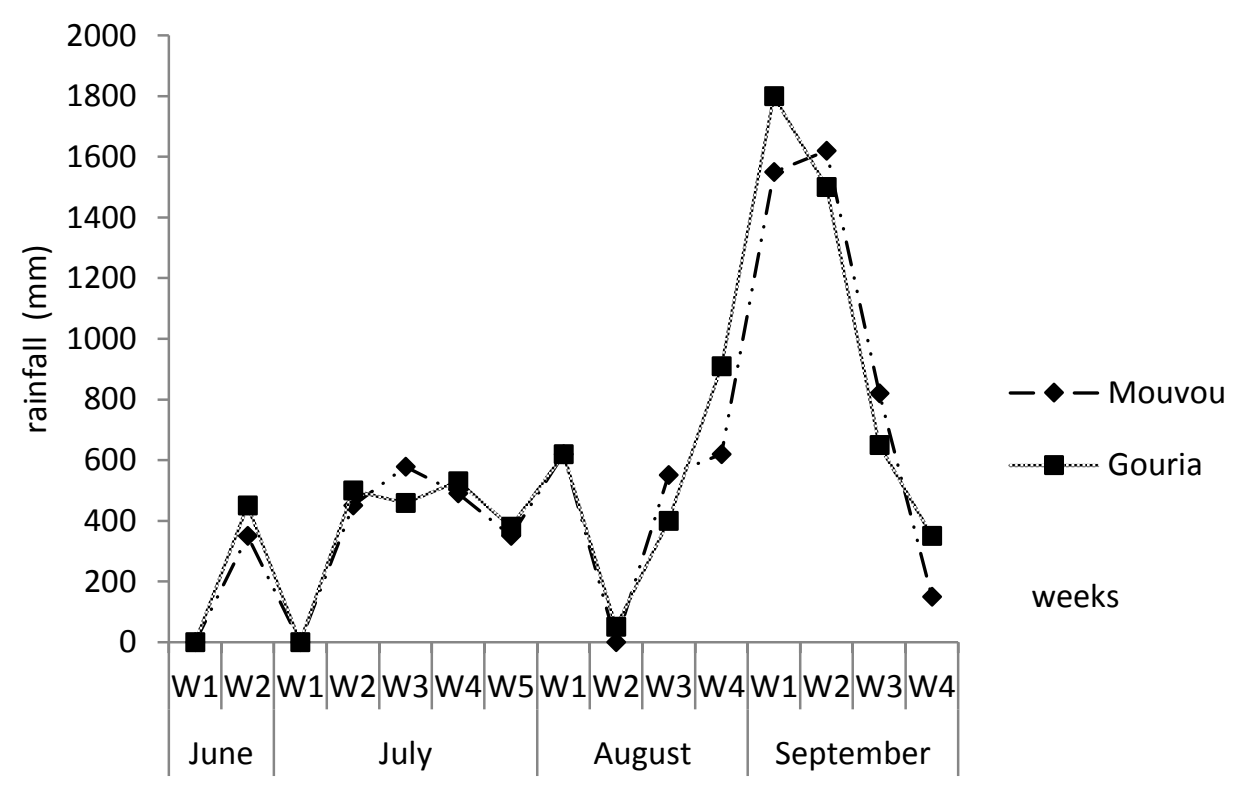

Figure 4: Evolution of rainfall in the two sites.

Table 2: average diameters, number of stem and yield of potato in the two sites.

\begin{tabular}{lcllll}
\hline \multicolumn{4}{l}{ Average diameter of tubers $(\mathbf{c m})$} & \multicolumn{4}{l}{ Number of stems } & \multicolumn{2}{l}{ Yield (t/ha) } \\
\hline Mouvou & Gouria & Mouvou & Gouria & Mouvou & Gouria \\
& & & & & \\
$3.24 \pm 0.61^{\mathrm{a}}$ & $3.34 \pm 0.75^{\mathrm{a}}$ & $2 \pm 1.38^{\mathrm{a}}$ & $18 \pm 0.75^{\mathrm{b}}$ & 3.52 & 3.80 \\
\hline \multicolumn{2}{c}{$\mathrm{P}=0.34$} & $\mathrm{P}=0.001$ & & $\mathrm{P}=0.39$ \\
\hline
\end{tabular}

The values followed by the same letter, for each parameter, are not significantly different at the 5\% threshold according to Duncan's test. 


\section{DISCUSSION}

The purpose of this work was to identify diseases and yield in potatoes production area in the Far North, Cameroon.

Potato production is confronted with diseases and pests including fungal (late blight, alternaria and fusarium), viral (Virosis M, Rust stain and PLR), bacterial (Bacterial wilt and common scab) diseases. These diseases appear from germination, and mainly during the vegetative growth, flowering, fruiting and harvesting phases. These results corroborate those of Andrivon et al. (2003), Delleman et al. (2005), who showed that the vegetative multiplication method by tuber promotes a great propagation of pathogens compared to multiplication by seed. The tubers harbor several pathogens. Furthermore, Anginyah et al. (2001), Olanya et al. (2001) and Ganie et al. (2013) have shown that, late blight and alternaria are the most important diseases in Kenya and in all of sub-Saharan Africa, and in Germany.

Many viral diseases such as virosis $\mathrm{M}$ (PVM) and rust spot have been observed during the vegetative growth phase. This can be explained by the fact that the presence of the young leaves, the flowers and the characteristic odors, attract many insects (very numerous in the semi-Sahelian zone) which are agents vector of the viral diseases. Issa et al. (2017) and Stuart et al. (2008) had also shown that the flowers of many plants attract pollinating insects which are considered to be vectors of viral diseases.

The incidence of disease observed at both sites was low $(<30 \%)$. This result is in contrary with that obtained by Lontsi et al. (2019) who obtained incidences on the order of $80 \%$ for late blight in Cameroon, but in the agro-ecological zone with bimodal rainfall. In addition, Lehtonen et al. (2004) obtained very high incidences of around $60 \%$ for common scab.

The almost homogeneous distribution of fungal and viral diseases in the two sites could be explained by the fact that the two sites are located in the same agro-ecological zone (Sudano-Sahelian zone). However, higher rainfall in Gouria may explain the higher incidence and severity of late blight and alternaria at both sites. Indeed, rainfall is very important in the spread of fungal diseases.

The plants received NPK as fertilizer. The absorption of nutrients by the roots of the plant is generally accompanied by direct penetration of pathogens into the plant, which may justify the presence and severity of the diseases at the sites. Lepoivre (2003) and Spooner (2005) have shown that mineral nutrition can affect plants by acting on the host or the parasite.

The yield was roughly the same at both sites. The diseases seem to have had an impact on incidences, severities and yield. In addition, the yield also depends on the fertilizer provided. Benbrahim and Sayed (2005), Jama et al. (2010) have also shown that, depending on the quantity of nutrients provided, the organic matter in the soil remains the important factor for maintaining its fertility and increased yields.

Finally, the diversity of pathogens recorded on potato in Far North is noteworthy. This may offer a potential for the development of sustainable control strategies against the economically important potato diseases.

\section{Conclusion}

This study revealed that potato are susceptible to diseases (late blight, Alternariaand Fusarium wilt, Virosis M, Rust stain, PLR, Bacterial wilt and Common scab) occurring on various plant organs. Among these disease, late blight and Alternaria (early blight) seem to be more important with higher incidence $(18.89 \%$ and $14.73 \%)$ and severity (22.49\% and $22.16 \%$ respectivily). The yield remains much lower (3.80 tonnes per hectare). The study of the impact of these diseases on yield should be undertaken.

\section{COMPETING INTERESTS}

The authors declare that they have no competing interests.

\section{AUTHORS' CONTRIBUTIONS}

This article is the result of the combined efforts of a multidisciplinary team of phytopathologists (JPND, FUB, MA, TDBT, 
$\mathrm{AH}, \mathrm{BD}, \mathrm{PK}$ and $\mathrm{ZA}$ ) who contribute to elaborate the protocol (experimental design and sampling (FUB, ZA, DBTT and DBHA) diseases and fungal identification (NDJP, DB, PK and AZ), growth parameters (DBHA). JPND drafted the manuscript which has been reviewed by all co-authors.

\section{REFERENCES}

Ah-Fong AM, Kim KS, Judelson HS. 2017. RNA-seq of life stages of the oomycete Phytophthora infestans reveals dynamic changes in metabolic, signal transduction, and pathogenesis genes and a major role for calcium signaling in development. BMC Genomics, 18(1):198. DOI : https://doi.org/10.1186/s12864-0173585 -

Abuley IK, Nielsen BJ. 2017. Evaluation of models to control potato early blight (Alternaria solani) in Denmark. Crop Prot., 102:118-128 DOI : https://doi.org/10.1016/j.cropro.2017.08. 012

Alkher H, Islam MR, Wijekoon C, Kalischuk M, Kawchuk LM, Peters RD, AlMughrabi KI, Conn KL, Dobinson KF, Waterer D, Daayf F. 2015. Characterization of Phytophthora infestans populations in Canada during 2012. Canadian Journal of Plant Pathology, 37(3): 305-314. DOI : https://doi.org/10.1080/07060661.2015.1 053987

Andrivon D, Lucas JM, Ellissèche D. 2003. Development of natural late blight epidemics in pure and mixed plots of potato cultivars with different levels of partial resistance. Plant Pathol., 52: 586594.

DOI :

https://doi.org/10.1046/j.1365-

3059.2003.00882.x.

Anginyah TJ, Narla RD, Carey EE, Njeru R. 2001. Etiology, effect of soil $\mathrm{pH}$ and sweet potato varietal reaction to alternaria leaf petiole and stem blight in Kenya. African Crop Science Journal, 9(1): 287292. DOI: 10.4314 /acsj.v9i1.27650

Baldo NH, Elhassan SM, Elballa MMA. 2010. Occurrence of Viruses Affecting Potato
Crops in Khartoum State-Sudan. Potato Res., 53: 61-67. DOI: https://doi.org/10.1007/s11540-0109150-5

Benbrahim K, Sayed I. 2005. Contribution à l'étude de l'intérêt de l'utilisation de la solarisation du sol dans les périmètres céréaliers sous pivot: cas de la ferme d'ERRIAD (Ourgla). Thèse de doctorat pH. D, Université de Ouargla, Maroc, p. 128.

Charkowski A, Sharma K, Parker ML, Secor GA, Elphinstone J. 2020. Bacterial diseases of potato. In The Potato Crop, Campos H, Ortiz O (eds). Springer: Cham; 351-388. DOI : https://doi.org/10.1007/978-3-03028683-5_10

Chiunga E, Valkonen JPT. 2013. First report on viruses infecting potato in Tanzania. Plant W. Dis., 97: 1260. DOI: 10.1094/PDIS-02-13-0143-PDN

Delleman J, Mulder A, Turkensteen LJ. 2005. Diseases, pests and defects. Aardappelwereld \& NIVAP (ed): Den Haag, Netherlands.

Diop P, Sylla ES, Diatte M, Labou B, Diarra K. 2019. Effect of cut seed tubers and pregermination on potato tuber yield. Int. J. Biol. Chem. Sci., 13(7): 3157-3163. DOI: https://dx.doi.org/10.4314/ijbcs.v13i7.15

FAO. 2009. La situation mondiale de l'alimentation et de l'agriculture. FAO. $202 \mathrm{p}$.

Fontem DA, Olanya OM, Tsopmbeng GR, Owona MAP. 2005. Pathogenicity and metalaxyl sensitivity of Phytophthora infestans isolates obtained from garden huckleberry, potato and tomato in Cameroon. Crop Protection, 24: 449-456. DOI:

https://doi.org/10.1016/j.cropro.2004.09. 012

Fontem DA. 2003. Quantitative effects of early and late blights on tomato yields in Cameroon. Tropicultura, 21: 36-41.

Ganie, SA, Ghani MY, Qazi N, Jabeen N, Anjum Q, Ahanger FA, Ayaz A. 2013. Status and symptomatology of earlyblight (Alternaria solani) of potato (Solanum 
tuberosum L.) in Kashmir valley. African Journal of Agricultural Research, 8(4): 5104-5115.

DOI: 10.5897/AJAR2013.7338

Habtamu K, Alemayehu C, Bekele K, Pananjay KT. 2012. Evaluation of different potato variety and fungicide combinations for the management of potato late blight (Phytophthora infestans) in Southern Ethiopia. Int. J. Life Sci., 1(1): 8-15.

IRAD. 2012. (Institut de Recherche Agricole pour le Développement). Amélioration durable de la productivité et de la compétitivité de la filière plantain au Cameroun par l'utilisation des technologies innovantes. IRAD, p.8.

Issa M, Ngakou A, Haouvang LC, Nukenine NE. 2017. Potentials of arbuscular mycorrhizafungi (AMF) and neem (AzadirachtaindicaA. Juss.) leaves extract as biological control agents against the sweet potato weevil (Cylas puncticollis Boch.) in two Agroecological zones of Cameroun. Journal of Experimental Agriculture Internation, 17(1): 1-13. DOI : https://doi.org/10.9734/JEAI/2017/35248

Jama B, Palm CA, Buresh RJ, Niang A, Gachengo C, Nziguheba G, Amadalo B. 2000. Tithoniadiversifoliaas a green manure for soil fertility improvement in Wertern Kenya. Agroforestery Systems, 49(2): 201-221. DOI : 10.1023/A:1006339025728

Kong HG, Bae JY, Lee HJ, Joo HJ, Jung EJ, Chung E, Lee S-W. 2014. Induction of the viable but nonculturable state of Ralstonia solanacearum by low temperature in the soil microcosm and its resuscitation by catalase. PLoS One, 9(10): e109792. DOI : https://doi.org/10.1371/journal.pone.010 9792

Kamaluddin G. 1970. A study of fungal diseases of potato in East Pakistan with special reference to those occurs in storage. M.Sc. Thesis, East Pakistan Agricultural University, Mymensingh, $110 \mathrm{p}$.
Lehtonen MJ, Rantala H, Kreuze JF, Bang H, Kuisma L, Koski P, Virtanen E, Vihlman K, Valkonen JPT. 2004. Occurrence and survival of potato scab pathogens (Streptomyces species) on tuber lesions: quick diagnosis based on a PCR-based assay. Plant Pathol., 53(3): 280-287. DOI : $\quad$ https://doi.org/10.1111/j.00320862.2004.01009.x

Lepoivre P. 2003. Phytopathologie. Les Presses Agronomiques de Gembloux: Belgique.

Lontsi SLD, Ambang Z, Djieto CL, Wouom BCC, Heu A, Pegalepo AN. 2019. Effect of aqueous extracts of Thevetia peruviana $\mathrm{K}$. seeds on the control of late blight and pest insects of Solanum tuberosum L. in Cameroon. Greener Journal of Agricultural Sciences, 9(1): 14-22. DOI: http://doi.org/10.15580/GJAS.2019.1.12 1418176.

Masum MMI, Islam SMM, Islam MS,Kabir MH. 2011. Estimation of loss due to post harvest diseases of potato in markets of different districts in Bangladesh. African Journal of Biotechnology, 10(56): 1189211902. DOI: $10.5897 / A J B 11.860$

Ngoyi AN, Masanga GK, Bila HM, Yashima AY, Milambo MM, Ndjibu LN, Baboy LL. 2020. Effet des amendements organiques sur la croissance et le rendement de la pomme de terre (Solanum tuberosum) cultivée sur un sol dégradé dans la région de Kabinda, République Démocratique du Congo. Int. J. Biol. Chem. Sci., 14(5): 1812-1819. DOI: https://doi.org/10.4314/ijbcs.v14i5.24

Njualem DK, Demo P, Mendoza HA, Koi JT, Nana SF. 2001. Reactions of some potato genotypes to late blight in Cameroon. African Crop Science Journal, 9(1): 209214.

DOI : http://dx.doi.org/10.4314/acsj.v9i1.2764 1

Olanya OM, Adipala E, Hakiza JJ, Kedera JC, Ojiambo P, Mukalazi JM, Forbes G,Nelson R. 2001. Epidemiology and population dynamics of Phytophthora infestans in Sub-Saharan Africa: Progress 
and constraints. African Crop Science Journal, 9(1): 185-194. DOI: 10.4314/acsj.v9i1.27638

Prior P, Ailloud F, Dalsing BL, Remenant B, Sanchez B, Allen C. 2016. Genomic and proteomic evidence supporting the division of the plant pathogen Ralstonia solanacearum into three species. $B M C$ Genomics, 17(1): $90 . \quad$ DOI : 10.1186/s12864-016-2413-z

Radtke W, Rieckmann W. 1991. Maladies et Ravageurs de la Pomme de Terre(ed). Editions Th. Mann.

Son D, Somda I, Legreve A, Schiffers B. 2018. Effect of plant diversification on pest abundance and tomato yields in two cropping systems in Burkina Faso: farmer practices and integrated pest management. Int. J. Biol. Chem. Sc., 12(1): 101-119. DOI : 10.4314/acsj.v9i1.27638
Stuart W, Platt HW, Nigel C. 2008. Diseases, Pests and Disorders of Potatoes - A Colour Handbook. Manson Publishing Ltd: London, UK.

Spooner DM, Mc Lean K, Ramsay G. 2005. A single domestication for potato based on miltilocus amplified fragment length polymorphism genotyping. Proc. Natl. Acad. Sci., 102: 14694-14699. DOI: $10.1073 /$ pnas.0507400102

Uaciquete A. 2013. Charactérization, epidemiology and control strategies for the anthracnose pathogène (Colletotrichum spp.) on cashew (Anacardium occidentale L.) in Mozambique. Ph.D. Thesis, University of Pretoria, Pretoria, p. 85. 